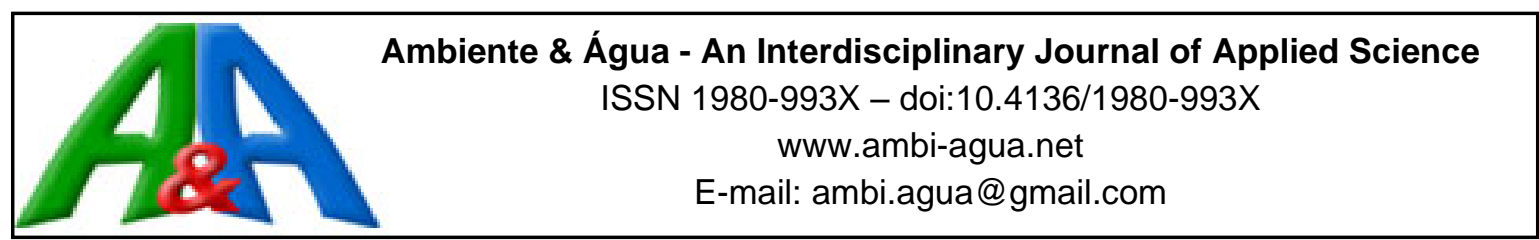

\title{
Risk of exposure to metals in soil contaminated by steel industry waste for a population in Volta Redonda, $\mathbf{R J}$
}

\author{
ARTICLES doi:10.4136/ambi-agua.2696
}

Received: 14 Jan. 2021; Accepted: 21 Jun. 2021

\begin{abstract}
Bruna Garcia Pagliari ${ }^{1 *}$; Maria de Fátima Ramos Moreira ${ }^{2}$ iD; Camille Ferreira Mannarino ${ }^{3}$; ;ideon Borges dos Santos ${ }^{2}$ (ic

${ }^{1}$ Escola Nacional de Saúde Pública Sergio Arouca. Fundação Oswaldo Cruz (Fiocruz), Rua Leopoldo Bulhões, $n^{\circ}$ 1480, CEP: 21041-210, Rio de Janeiro, RJ, Brazil.

${ }^{2}$ Centro de Estudos da Saúde do Trabalhador e Ecologia Humana. Escola Nacional de Saúde Pública Sergio Arouca. Fundação Oswaldo Cruz (Fiocruz), Rua Leopoldo Bulhões, nº 1480, CEP: 21041-210,

Rio de Janeiro, RJ, Brazil. E-mail: mfr.moreira55@gmail.com, gidborgess@gmail.com

${ }^{3}$ Departamento de Saneamento e Saúde Ambiental. Escola Nacional de Saúde Pública Sergio Arouca. Fundação

Oswaldo Cruz (Fiocruz), Rua Leopoldo Bulhões, n 1480, CEP: 21041-210, Rio de Janeiro, RJ, Brazil.

E-mail: camille.mannarino@gmail.com

*Corresponding author. E-mail: brunapagliari@poli.ufrj.br
\end{abstract}

\begin{abstract}
The aim of this study was to identify the risk of population's exposure, by different exposure routes, to $\mathrm{Zn}, \mathrm{Ni}, \mathrm{Cu}, \mathrm{Cr}$, and $\mathrm{Pb}$ in the soil of a condominium. Six sampling points in three campaigns provided thirty-six soil samples, collected at two depths, one superficial, 0.20 $\mathrm{m}$, and the other underground, between 2.00 and $3.00 \mathrm{~m}$. The results show that the levels of metals in the condominium's soil are generally high. Children cannot withstand the same doses as adults since they are more susceptible and risk greater damage to health. The noncarcinogenic risk based on the hazard quotient (HQ) and the health index (HI) values for each exposure pathway and for each metal were observed to be less than $(<) 1$. The results showed an immediate carcinogenic risk by chromium ingestion for children. Nevertheless the combined effect for each exposure pathway (TCRI) for adults is close to becoming unacceptable after exposure to $\mathrm{Cr}$ by ingestion. The results suggest that contamination by metals is more likely to occur among children than adults at similar exposure levels. Thus, the condominium built on an area contaminated by steel industry waste raises concern, requiring the continuous monitoring of its population.
\end{abstract}

Keywords: environment pollution, industrial waste, metals, soil, steel industry.

\section{Risco da exposição a metais em solo contaminado por resíduos da indústria siderúrgica para uma população em Volta Redonda, RJ}

\section{RESUMO}

O objetivo desse estudo foi identificar o risco de exposição ao $\mathrm{Zn}, \mathrm{Ni}, \mathrm{Cu}, \mathrm{Cr}$ e $\mathrm{Pb}$ no solo de um condomínio para a população residente por diferentes vias de exposição. Seis pontos de amostragem em três campanhas forneceram trinta e seis amostras de solo, coletadas em duas profundidades, uma superficial, $0,20 \mathrm{~m}$, e outra subterrânea entre 2,00 e 3,00 m. Os resultados mostram que os níveis de metais no solo do condomínio são em geral elevados. As crianças não

This is an Open Access article distributed under the terms of the Creative Commons Attribution License, which permits unrestricted use, distribution, and reproduction in any medium, provided the original work is properly cited. 
podem ser expostas à mesma dose que os adultos, uma vez que são mais suscetíveis e podem ter maiores danos na saúde. O risco não cancerígeno com base no quociente de risco $(\mathrm{QR})$ e nos valores do índice de saúde (IS) para cada via de exposição e para cada metal foram observados como sendo menores que $(<) 1$. Os resultados mostraram um risco carcinogênico imediato pela ingestão de cromo em crianças. No entanto, o efeito combinado para cada via de exposição (TCRI) para adultos está perto de se tornar inaceitável após a exposição ao Cr por ingestão. Os resultados sugerem que em níveis de exposição semelhantes, as crianças terão maior probabilidade de contaminação por metais do que os adultos. Desta forma, o condomínio construído sobre área contaminada por resíduos da indústria siderúrgica gera preocupação, devendo essa população ser monitorada.

Palavras-chave: indústria siderúrgica, metais, poluição ambiental, resíduos industriais, solo.

\section{INTRODUCTION}

The socio-environmental impacts caused by the steel industry have fostered scientific discussions and research on the relationship between humans and the environment, as well as its consequences on a global scale (Masindi and Muedi, 2018).

The production processes in the steel industry release a wide variety of hazardous chemicals, posing high risks for the environment and consequently to the health of living beings (Rosenfeld and Feng, 2011). Thus, this type of industry can generate several occupational and socio-environmental risks. It demands a high amount of energy to process input products to obtain steel, which generates a large amount of waste, such as dust, blast furnace mud, steelmaking slag, coal fines, etc. (CETEM, 2013a).

The steel industry releases several substances into the atmosphere, soil, and water, such as particulate matter (PM), nitrogen (NOx) and sulfur oxides (SOx), carbon monoxide (CO), metals, aromatic compounds, dioxins, furans, benzene, toluene, ethylbenzene and xylene (BTEX), and polycyclic aromatic hydrocarbons (HPAs) (Lawton et al., 2014; Hsu et al., 2017).

The release of these substances is mainly during the transport and storage of raw materials (charcoal and ore), vehicle traffic, coconut shell charcoal production (loading, coking, oven pushing, and steam generation), sintering (sintering machine), blast furnace (air blowing and heating), steelmaking, casting, and thermoelectric power station (CETEM, 2013a).

During blast furnace operation, suspended solids (SS), zinc (Zn), cyanides, and fluorides contaminate effluents. Burning coal for energy produces toxic effluents, including mercury $(\mathrm{Hg})$, vanadium $(\mathrm{V})$, cadmium $(\mathrm{Cd})$, arsenic $(\mathrm{As})$, and lead $(\mathrm{Pb})$. Likewise, steel refining causes effluents to have high concentrations of suspended solids, oils, and metals such as copper $(\mathrm{Cu})$, lead $(\mathrm{Pb})$, chromium $(\mathrm{Cr})$, and nickel $(\mathrm{Ni})$. The solid wastes resulting from steel production are oils and greases, blast furnace slag, coal fines, gas cleaning sludge, and dust (CETEM, 2013a; Motuzova et al., 2014).

Steelmaking slag is an important metallurgical solid waste whose chemical composition may vary according to the raw material used, production process, conversion coating, type of steel produced, and slag cooling and storage, forming calcium silicates and ferrites combined with cast-iron oxides, aluminum, manganese, calcium, magnesium, among other chemical substances (Zhang et al., 2014). The solid waste generated in the process of steelmaking must be treated before its disposal, since even steelmakers with effluent treatment plants cannot eliminate pollutants, only transfer them, transforming effluents into solid waste (CETEM, 2013a).

Volta Redonda is home to one of Latin America's largest steel companies. However, reports of irregularities have attracted the attention of the media and the Federal Public Ministry since its inauguration. This company donated a plot of land to the employees to build a 
condominium. Until then, the steelmaker had used this land to dispose of tons of hazardous waste, neglecting regulations and environmental licensing processes (Brasil, 2012; CETEM, 2013b). The company has deposited large amounts of steel slag on the site next to the houses since that time. Not only was the condominium built over industrial waste, but it also is located within less than 30 meters from the area currently used for storing and processing steelmaking slag (Brasil, 2015). Nowadays, a 30-meter-high "pile" of waste outgrows the site's walls, and it is less than 50 meters from the Paraíba do Sul River.

For this study, we selected the elements zinc, nickel, copper, chromium, and lead due to their widespread use within the steel industry and their toxicity. Although an essential element in the human body, zinc levels above the maximum permissible limits may induce hematological, respiratory, gastrointestinal, neurological, immunological, dermal, ocular, and systemic effects (Plum et al., 2010). Accumulation of $\mathrm{Ni}$ and its compounds in the body through chronic exposure can affect the cardiovascular and respiratory systems, skin, liver and induce genotoxic, teratogenic, and carcinogenic effects (Soares et al., 2011; Genchi et al., 2020). Like zinc, copper is an essential element for human beings. However, levels above the maximum permissible limits may induce neurological, psychiatric, hematological, or hepatic effects (Sócio et al., 2010). Chromium is an important causative agent of contact dermatitis among workers, and it can also cause chronic skin ulcers and nasal septum perforations due to its corrosive properties. Trivalent chromium is an essential nutrient in humans, whereas chronic exposure to $\mathrm{Cr}$ (VI) compounds is mainly associated with carcinogenic effects (Singhal et al., 2015). Lead is a highly toxic metal, even at trace exposure levels, responsible for severe damage to the nervous, hematological, renal, cardiovascular, gastrointestinal, and reproductive systems (Sall et al., 2020). The International Agency for Research on Cancer (IARC) classifies chromium (Cr) and nickel (Ni) as Group 1, carcinogenic to humans, being mainly associated with lung, nasal, and nasopharyngeal cancer. In turn, lead $(\mathrm{Pb})$ is categorized as Group $2 \mathrm{~A}$, probably carcinogenic to humans, as only the evidence in animals is conclusive. Metals demonstrate a high tendency to bioaccumulate in the environment. These elements often exist at low concentrations, but anthropic activities commonly induce high concentration levels (IARC, 2012).

This study aimed to estimate the risk to human health through multi-pathway exposure routes caused by metal concentrations $(\mathrm{Zn}, \mathrm{Ni}, \mathrm{Cu}, \mathrm{Cr}$, and $\mathrm{Pb}$ ) in soil samples from nonwaterproofed public areas in a condominium of Volta Redonda - RJ.

\section{MATERIALS AND METHODS}

\subsection{Study area}

The evaluated site was a condominium in Volta Redonda, a municipality in the Vale do Paraíba microregion, Southern Rio de Janeiro $\left(182,483 \mathrm{Km}^{2}\right)$, on the Rio - São Paulo axis. The Paraíba do Sul River crosses the municipality, flows west to east, and is the primary source of water supply for more than 12 million people in the state, among which $85 \%$ are metropolitan region residents. The region's upland areas present deep, acidic clay soils with low porosity; in turn, lowland areas at the riverbanks are predominantly composed of fertile soils rich in organic matter. The municipality has a population of 257,803 inhabitants, with 1,412.75 inhabitants per $\mathrm{Km}^{2}$. The condominium is located in the Santo Agostinho neighborhood - in the east part of the municipality, between the right Paraíba do Sul riverbank and the Lúcio Meira highway (BR393). It consists of 808 properties, divided into eight blocks, with approximately 3,000 dwellers. According to INEA, the area is classified as a contaminated area under intervention (ACI) (INEA, 2014; Brasil, 2012; 2015). 


\subsection{Soil sampling}

Approximately 4-meter-high walls separate the condominium blocks. All sidewalks, streets, backyards, blocks, and squares were waterproofed so the population would not have direct contact with the soil. The collection of superficial and underground soil samples in nonwaterproofed public areas of the condominium contributed to analyzing the area's current situation, mainly in its surroundings, considering the distance from the steelmaking slag landfill.

Soil sampling took place at the same six points in three campaigns (Figure 1). The points were georeferenced, and soil surface samples ("A") were collected at an average depth of 0.20 $\mathrm{m}$, and underground samples ("B") at a mean depth ranging between 2.00 and $3.00 \mathrm{~m}$, depending on the water level. During collection and transport to the laboratory, samples were kept in duly identified glass bottles $(1000 \mathrm{~mL})$ and refrigerated-stored in a thermal box at $4^{\circ} \mathrm{C}$.

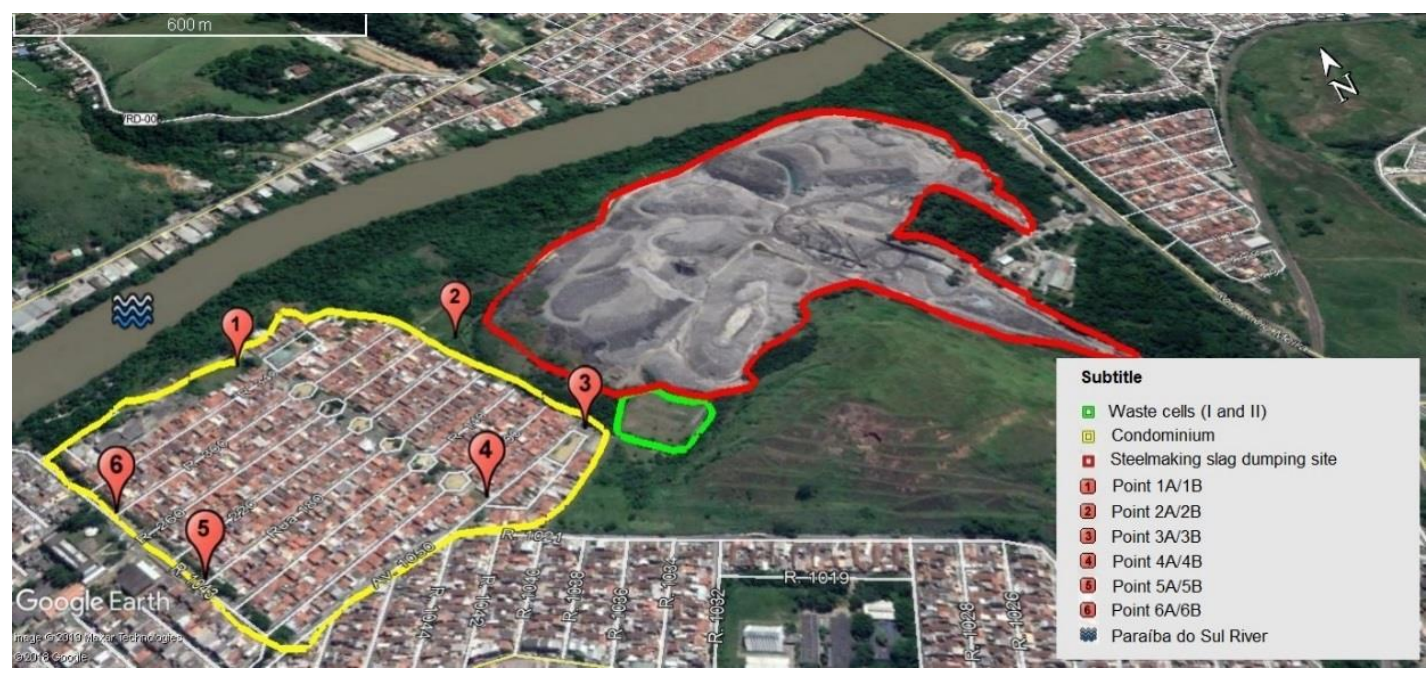

Figure 1. Soil samples collection points in the Volta Redonda condominium.

Source: Google Earth, 2019.

The first campaign was carried out on a sunny day in June 2018 with a temperature of $32^{\circ} \mathrm{C}$. Although the rains are constant in the city regardless of the season, one of the driest months in Volta Redonda is June. The average wind speed was $13.2 \mathrm{~km} \mathrm{~h}^{-1}$ in the northnortheast direction.

The two other campaigns were executed in September 2019 and May 2020. In both samplings, the days were cloudy. In September, the climate conditions were a temperature equal to $20^{\circ} \mathrm{C}$ and an average wind speed of $9.2 \mathrm{~km} \mathrm{~h}^{-1}$ in the south direction. The sampling in May experienced intermediate conditions with a temperature of $25^{\circ} \mathrm{C}$ and average wind speed of 10.5 $\mathrm{km} \mathrm{h}^{-1}$ in the northern direction.

The land slope causes the water to seep through the condominium's waterproofed canals (streets, sidewalks, squares, blocks) towards the Paraíba do Sul River during rainfall periods. Sampling points were delimited based on the fluid contamination path during precipitation and the distance from the steelmaking slag landfill, considering those closer to the "pile" (Points 2 and 3), intermediate points (Points 1 and 4), and those further away (Points 5 and 6). A shelltype hand auger (ABNT, 2007) of 4" nominal diameter performed the soil sampling.

\subsection{Experimental}

A laboratory certified by the State Environmental Institute (INEA)/RJ analyzed the samples, and a Perkin Elmer (Norwalk, CT., USA) Optima 8300 ICP OES spectrometer performed the measurements of the metals of interest $(\mathrm{Zn}, \mathrm{Ni}, \mathrm{Cu}, \mathrm{Cr}$, and $\mathrm{Pb}$ ) according to the 
SM-3120B method (APHA et al., 2012).

A mixture of nitric and hydrochloric acids digested the soil samples, and the solution was heated to reduce volume. Filtration was then carried out, and deionized water completed the volume. After the digestion process of the samples, the ICP OES performed the determination of the total metal content. The acid digestion used as a pretreatment followed the EPA Method 3005A - "Acid digestion of waters for total recoverable or dissolved metals for analysis by FLAA or ICP spectroscopy". Calibration curves were prepared using blank samples spiked with adequate micro-volumes of the standard solutions for each metal, and laboratory-made reference materials checked the accuracy of the procedure. Limits of detection (LOD) and quantification (LOQ) of the method were 0.07 and $0.25 \mathrm{mg} \mathrm{Kg}^{-1}$, respectively.

\subsection{Health risk}

The potential carcinogenic and non-carcinogenic risks that may arise from the exposure of adults and children living in the study area to metals in the soil were determined by combining exposure pathways. These risk pathways involve acceptable daily intake (ADI) of metals (mg $\mathrm{Kg}^{-1}$ ) through ingestion (Ing), inhalation (Inal), or dermal exposure (Derm) using the methods described in Equations 1, 2, and 3 (Lange, 2018; Bwatanglang et al., 2019).

$$
\begin{aligned}
& A D I_{\text {Ing }}=\frac{C_{\text {Soil }} \times R_{\text {Ing }} \times E F \times E D}{B W \times A T \times 10^{6}} \\
& A D I_{\text {Inal }}=\frac{C_{\text {Soil }} \times R_{\text {Inal }} \times E F \times E D}{B W \times A T \times P E F} \\
& A D I_{\text {Derm }}=\frac{C_{\text {Soil }} \times S S \times D S A F \times D A F \times E F \times E D}{B W \times A T \times 10^{6}}
\end{aligned}
$$

$\mathrm{ADI}_{\text {Ing }}$ represents the ingestion pathway, $\mathrm{ADI}_{\text {Inal }}$ inhalation, and $\mathrm{ADI}_{\text {Derm }}$ dermal contact. Other parameters and their corresponding functions are described in Table 1. The exposure

\begin{tabular}{|c|c|c|c|c|}
\hline Factors & Unit & Children & Adults & References \\
\hline $\begin{array}{l}\text { Soil concentration }\left(\mathrm{C}_{\text {Soil }}\right) \text { - } 95 \% \text { Upper } \\
\text { confidence limit (UCL) }\end{array}$ & $\mathrm{mg} \mathrm{Kg}{ }^{-1}$ & \multicolumn{2}{|c|}{$\begin{array}{c}\text { The maximum value of } \\
\text { the arithmetic mean in } \\
\text { the } 95 \% \text { confidence } \\
\text { interval }\end{array}$} & (USEPA, 1992) \\
\hline Ingestion rate $\left(\mathrm{R}_{\text {Ing }}\right)$ & $\mathrm{mg} \mathrm{day}^{-1}$ & 200 & 100 & (USEPA, 2002) \\
\hline Exposure frequency (EF) & days year ${ }^{-1}$ & 122 & 122 & $\begin{array}{l}\text { (Gabarrón et al., } \\
\text { 2017). }\end{array}$ \\
\hline Exposure duration (ED) & Years & 6 & 24 & (USEPA, 2002) \\
\hline $\begin{array}{l}\text { Body weight (BW) } \\
\text { Average time (AT) }\end{array}$ & $\mathrm{Kg}$ & 15 & 70 & (USEPA, 1986) \\
\hline $\begin{array}{l}\text { Carcinogens } \\
\text { Non-carcinogens }\end{array}$ & Days & $\begin{array}{r}70 \times 365 \\
D E \times 365\end{array}$ & $\begin{array}{l}70 \times 365 \\
D E \times 365\end{array}$ & (USEPA, 1989) \\
\hline Inhalation rate $\left(\mathrm{R}_{\text {Inal }}\right)$ & $\mathrm{m}^{3}$ & 7.6 & 20 & $\begin{array}{c}\text { Children (Lu et al., } \\
\text { 2014); } \\
\text { Adults (USEPA, } \\
\text { 1986) }\end{array}$ \\
\hline Particulate emission factor (PEF) & $\mathrm{m}^{3} \mathrm{Kg}^{-1}$ & $1.32 \times 10^{9}$ & $1.32 \times 10^{9}$ & (USEPA, 1996) \\
\hline Skin surface (SS) & $\mathrm{cm}^{-2}$ & 8000 & 5700 & \\
\hline Dermal soil absorption factor (DSAF) & $\mathrm{mg} \mathrm{cm}^{-2}$ & 0.2 & 0.07 & (USEPA, 2004) \\
\hline Dermal absorption factor (DAF) & - & 0.001 & 0.001 & \\
\hline
\end{tabular}
factors used in this study are based on the study carried out by Gabarrón et al. (2017).

Table 1. Exposure factors used to identify health risk through different soil exposure pathways.

Source: Gabarrón et al. (2017); Lange (2018). 
The hazard quotient (HQ) was used to analyze the potential non-carcinogenic effect of metals in soil samples, relating ADI with its reference dose (RfD) (Table 2) for each exposure and contaminant pathway (c), as described in Equation 4 (Lange, 2018; Bwatanglang et al., 2019).

$$
\mathrm{HQ}=\mathrm{ADI}_{\mathrm{c}} / \mathrm{RfD}_{\mathrm{c}}
$$

Table 2. Each metal reference dose $\left(\mathrm{RfD}, \mathrm{mg} \mathrm{Kg}^{-1}\right)$ and cancer slope factor (CSF) by exposure pathway.

\begin{tabular}{cccccc}
\hline & $\mathrm{Zn}$ & $\mathrm{Ni}$ & $\mathrm{Cu}$ & $\mathrm{Cr}$ & $\mathrm{Pb}$ \\
\hline RfD $_{\text {Ing }}$ & $3.00 \mathrm{E}-01$ & $2.00 \mathrm{E}-02$ & $4.00 \mathrm{E}-02$ & $3.00 \mathrm{E}-03$ & $3.50 \mathrm{E}-03$ \\
$\mathrm{RfD}_{\text {Inal }}$ & $3.00 \mathrm{E}-01$ & $6.00 \mathrm{E}-06$ & $4.00 \mathrm{E}-02$ & $2.86 \mathrm{E}-05$ & $3.50 \mathrm{E}-03$ \\
RfD $_{\text {Derm }}$ & $3.00 \mathrm{E}-01$ & $8.00 \mathrm{E}-04$ & $4.00 \mathrm{E}-02$ & $7.50 \mathrm{E}-05$ & $7.00 \mathrm{E}-03$ \\
$\mathrm{CSF}_{\text {Ing }}$ & - & - & - & $5.00 \mathrm{E}-01$ & $8.50 \mathrm{E}-03$ \\
$\mathrm{CSF}_{\text {Inal }}$ & - & $9.80 \mathrm{E}+00$ & - & $4.10 \mathrm{E}-01$ & $4.20 \mathrm{E}-02$ \\
$\mathrm{CSF}_{\text {Derm }}$ & - & $9.80 \mathrm{E}+00$ & - & $2.00 \mathrm{E}-01$ & $8.50 \mathrm{E}-03$ \\
\hline
\end{tabular}

Source: Lange (2018); Bwatanglang et al. (2019).

As described in Equation 5, the health index (HI) for various contaminants, expressed as HQ sum for each contaminant (c), describes the non-carcinogenic cumulative effect of their combination in soil samples (Lange, 2018; Bwatanglang et al., 2019).

$$
\mathrm{HI}=\Sigma \mathrm{HQ}_{\mathrm{c}}=\mathrm{HQ}_{\text {Ing }}+\mathrm{HQ}_{\text {Inal }}+\mathrm{HQ}_{\text {Derm }}
$$

The cancer risk index (CRI) represents the likelihood of an individual developing any cancer throughout his or her lifetime and is calculated by combining ADI with each contaminant (c) cancer slope factor (CSF). Equation 6 describes such an index (Lange, 2018; Bwatanglang et al., 2019).

$\mathrm{CRI}=\mathrm{ADI}_{c} \times \mathrm{CSF}_{c}$

$\mathrm{HQ}$ or $\mathrm{HI}<1$ indicates no associated risk; that is, the exposed population is unlikely to present any adverse health effect. In turn, HQ or HI $>1$ raise genuine concern. CRI is considered negligible if $<10^{-6}$, acceptable or tolerable if $10^{-6}<\mathrm{CRI}<10^{-4}$, and high if $>10^{-4}$ (Lange, 2018; Bwatanglang et al., 2019).

Equation 7 provides a complete picture of an individual's lifelong cancer risk by combining all metals and exposure pathways (Lange, 2018; Bwatanglang et al., 2019).

$$
\mathrm{TCRI}=\Sigma \mathrm{TCRI}_{C}=\mathrm{CRI}_{\text {Ing }}+\mathrm{CRI}_{\text {Inal }}+\mathrm{CRI}_{\text {Derm }}
$$

TCRI represents the combined effect for each exposure pathway, TCRIc is the combined effect for each exposure pathway and each contaminant (c), CRI Ing exposure by ingestion, CRI Inal by inhalation, and CRI Derm by dermal contact.

\section{RESULTS AND DISCUSSION}

\subsection{Metal concentrations in soils}

Table 3 shows averages and standard deviations for $\mathrm{Zn}, \mathrm{Ni}, \mathrm{Cu}, \mathrm{Cr}$, and $\mathrm{Pb}$ concentrations in soil samples from non-waterproofed public areas of a condominium in Volta Redonda - RJ. 
Table 3. Average $\left(\mathrm{mg} \mathrm{Kg}^{-1}\right)$ and standard deviation for metals concentration in soil samples of a residential condominium in Volta Redonda, RJ.

\begin{tabular}{cccccc}
\hline Samples & $\mathrm{Zn}$ & $\mathrm{Ni}$ & $\mathrm{Cu}$ & $\mathrm{Cr}$ & $\mathrm{Pb}$ \\
\hline P-1A & $130.5 \pm 95.7$ & $13.3 \pm 4.7$ & $17.0 \pm 5.7$ & $55.5 \pm 27.3$ & $21.1 \pm 12.7$ \\
P-1B & $100.3 \pm 32.7$ & $14.8 \pm 1.3$ & $20.2 \pm 3.9$ & $38.6 \pm 7.5$ & $25.3 \pm 9.0$ \\
P-2A & $111.2 \pm 53.5$ & $20.3 \pm 9.1$ & $28.1 \pm 11.0$ & $47.7 \pm 6.0$ & $18.0 \pm 1.8$ \\
P-2B & $71.5 \pm 23.7$ & $14.2 \pm 6.1$ & $20.7 \pm 9.5$ & $39.3 \pm 6.2$ & $19.6 \pm 10.8$ \\
P-3A & $74.6 \pm 23.1$ & $13.8 \pm 2.6$ & $11.8 \pm 10.1$ & $70.5 \pm 24.8$ & $12.2 \pm 4.2$ \\
P-3B & $82.2 \pm 41.9$ & $14.0 \pm 2.7$ & $18.5 \pm 5.6$ & $85.5 \pm 46.1$ & $21.8 \pm 14.9$ \\
P-4A & $63.8 \pm 26.9$ & $10.6 \pm 8.5$ & $21.1 \pm 17.5$ & $51.2 \pm 19.5$ & $18.7 \pm 6.5$ \\
P-4B & $45.5 \pm 42.7$ & $8.7 \pm 5.2$ & $13.8 \pm 6.8$ & $45.5 \pm 1.5$ & $20.1 \pm 7.0$ \\
P-5A & $80.1 \pm 30.8$ & $7.7 \pm 0.9$ & $14.7 \pm 8.0$ & $36.7 \pm 9.3$ & $23.2 \pm 4.3$ \\
P-5B & $69.1 \pm 26.3$ & $7.6 \pm 0.4$ & $13.0 \pm 4.1$ & $29.5 \pm 4.4$ & $21.7 \pm 9.5$ \\
P-6A & $36.3 \pm 10.0$ & $8.4 \pm 3.4$ & $12.3 \pm 8.4$ & $41.7 \pm 10.1$ & $14.7 \pm 2.4$ \\
P-6B & $51.2 \pm 22.0$ & $7.0 \pm 5.7$ & $11.2 \pm 10.3$ & $30.1 \pm 12.5$ & $54.3 \pm 75.9$ \\
\hline
\end{tabular}

Resolution $n^{\circ}$. 420/2009, from the National Environment Council (NEC) in Brazil, establishes three classes of guiding values for soils, the quality reference value (QRV), the prevention value (PV), and the intervention value (IV). QRV is the concentration of a certain substance, which defines soil as clean, used as a reference in the prevention and control of contamination. PV is the concentration above which harmful changes in soil quality can occur, with consequences for humans and animals, and preventive measures against contamination must be used. Finally, IV is the concentration above which there are potential risks to human health. However, each state establishes its own QRV. The Company of Technology and Basic Sanitation of the State of São Paulo (CETESB) prepared a list with guiding values for the concentration of metals, among others, in soil, which will be used for comparing since they are the same as NEC, except the QRV (CETESB, 2016).

To obtain the human health risk indices after the exposure to the contaminated soil by any exposure pathway, metal concentrations in the surface soil were also compared to permissible levels (PL) in food for human consumption. PL for agricultural soils could be harmful to human health in case of ingestion, inhalation, or contact with the skin (Tóth et al., 2016; Bwatanglang et al., 2019).

Zinc average concentration in surface samples ranged from 36.3 to $130.5 \mathrm{mg} \mathrm{Kg}^{-1}$, much higher than those established by the Food and Agriculture Organization/World Health Organization (FAO, 2011), of $2.0 \mathrm{mg} \mathrm{Kg}^{-1}$, as well as the QRV $\left(60 \mathrm{mg} \mathrm{Kg}^{-1}\right)$ and PV (86 mg $\mathrm{Kg}^{-1}$ ) from CETESB, except Point 6A (CETESB, 2016). A study carried out in the cities of Mariana and Barra Longa, Minas Gerais State, assessed the health impacts of Fundão Dam breach-derived metals using surface soil samples. The authors found zinc concentration to range from 0.01 to $18.62 \mathrm{mg} \mathrm{Kg}^{-1}$ in Mariana and 0.01 to $32.35 \mathrm{mg} \mathrm{Kg}^{-1}$ in Barra Longa, values well below those found in the condominium (Silva et al., 2019). In Nigeria, a study was conducted to investigate the health impacts of traffic-derived metals using surface soil samples. The authors found zinc concentration to range from 6.72 to $13.57 \mathrm{mg} \mathrm{Kg}^{-1}$, also values well below those found in the condominium (Bwatanglang et al., 2019). However, two other studies also conducted in Nigeria reported much higher concentration levels. One of the studies (Tsafe et al., 2012) found values equal to $68.91 \mathrm{mg} \mathrm{Kg}^{-1}$, while the other (Ogundele et al., 2015) obtained a zinc concentration range between 30.8 and $219.23 \mathrm{mg} \mathrm{Kg}^{-1}$, similar to or higher than the findings in Volta Redonda.

The FAO (2011) has established a value of $0.20 \mathrm{mg} \mathrm{Kg}^{-1}$ for nickel concentration, much lower than those found in surface samples ranging from 7.7 to $20.3 \mathrm{mg} \mathrm{Kg}^{-1}$. On the other hand, CETESB has established QRV and PV equal to 13 and $30 \mathrm{mg} \mathrm{Kg}^{-1}$ (CETESB, 2016), respectively, which means that the levels found in such samples are following the legislation. Nickel values reported in both studies from MG, Mariana (0.05 to $4.59 \mathrm{mg} \mathrm{Kg}^{-1}$ ) and Barra 
Longa ( 0.005 to $13.49 \mathrm{mg} \mathrm{Kg}^{-1}$ ), and the other from Nigeria (1.83 to $14.87 \mathrm{mg} \mathrm{Kg}^{-1}$ ) were similar to or lower than those found in the condominium (Silva et al., 2019; Ogundele et al., 2015). Another study also developed in Nigeria found nickel concentration in surface soil samples ranging from 0.16 to $0.42 \mathrm{mg} \mathrm{Kg}^{-1}$, values well below those present in the condominium (Bwatanglang et al., 2019).

The average copper concentration in surface samples was much higher than $0.20 \mathrm{mg} \mathrm{Kg}^{-1}$ established by the FAO (2011), but well below 35 (QRV) and $60 \mathrm{mg} \mathrm{Kg}^{-1}$ (PV) accepted by CETESB (CETESB, 2016), ranging from 11.8 to $28.1 \mathrm{mg} \mathrm{Kg}^{-1}$. The studies conducted in Mariana and Barra Longa also reported copper concentrations below those found in the condominium. The copper concentrations ranged from 0.002 to $8.29 \mathrm{mg} \mathrm{Kg}^{-1}$ in Mariana and 0.002 to $10.32 \mathrm{mg} \mathrm{Kg}^{-1}$ in Barra Longa (Silva et al., 2019). Copper concentrations (0.14 to 0.17 $\mathrm{mg} \mathrm{Kg} \mathrm{K}^{-1}$ ) in another study from Nigeria were well below those found in the condominium (Bwatanglang et al., 2019). In turn, another investigation from the same country reported a concentration range between 4.83 and $80.13 \mathrm{mg} \mathrm{Kg}^{-1}$ (Ogundele et al., 2015), values similar and much higher than our results.

Average chromium concentration in surface samples ranged from 36.7 to $70.5 \mathrm{mg} \mathrm{Kg}^{-1}$. According to CETESB, QRV is equal to $40 \mathrm{mg} \mathrm{Kg}^{-1}$, while PV is $75 \mathrm{mg} \mathrm{Kg}^{-1}$ (CETESB, 2016). Therefore, the levels in such samples comply with the current legislation. On the other hand, those values are much higher than $0.50 \mathrm{mg} \mathrm{Kg}^{-1}$, accepted by the FAO (2011). Two studies carried out in Nigeria reported chromium levels lower than those found in the condominium. Their results were equal to $16.73 \mathrm{mg} \mathrm{Kg}^{-1}$ (Tsafe et al., 2012) and ranged from 0.01 and 0.07 mg Kg-1 (Bwatanglang et al., 2019). However, another reported chromium concentrations between 10.57 and $77.10 \mathrm{mg} \mathrm{Kg}^{-1}$ (Ogundele et al., 2015), comprising lower, similar, and higher values than in the current research.

Lead average concentrations in surface samples ranged from 12.2 to $23.2 \mathrm{mg} \mathrm{Kg}^{-1}$, which is also according to the QRV (17 $\left.\mathrm{mg} \mathrm{Kg}^{-1}\right)$ and PV (72 $\left.\mathrm{mg} \mathrm{Kg}^{-1}\right)$ (CETESB, 2016). However, these values are much higher than those established by FAO (2011), $0.35 \mathrm{mg} \mathrm{Kg}^{-1}$. In Mariana and Barra Longa, lead levels found were similar and lower than those from Volta Redonda. In such cities, lead concentrations varied from 0.005 to $12.63 \mathrm{mg} \mathrm{Kg}^{-1}$ in the former and 0.005 to $8.47 \mathrm{mg} \mathrm{Kg}^{-1}$ in the last one (Silva et al., 2019). Three studies in Nigeria assessed the lead concentration in surface soil samples. All samples presented an average concentration of 0.86 $\pm 0.06 \mathrm{mg} \mathrm{Kg}^{-1}$, well below that found in the condominium (Bwatanglang et al., 2019). However, the other two reported values, $29.66 \mathrm{mg} \mathrm{Kg}^{-1}$ (Tsafe et al., 2012) and a concentration range from 24 to $157.66 \mathrm{mg} \mathrm{Kg}^{-1}$ (Ogundele et al., 2015), are higher than in Volta Redonda.

\subsection{Health risk indices}

Table 4 presents the acceptable daily intake (ADI) by metal and exposure pathway for adults and children. In turn, Tables 5 and 6 highlight the possible non-carcinogenic and carcinogenic risks for $\mathrm{Zn}, \mathrm{Ni}, \mathrm{Cu}, \mathrm{Cr}$, and $\mathrm{Pb}$ in superficial soil samples from a condominium in Volta Redonda by different exposure pathways (ingestion, inhalation, and dermal).

Based on the exposure factors listed in Table 1, we found the ADI by metal and exposure pathway (Table 4) for adults and children to be lower than the reference dose (RfD) (Table 2). The acceptable daily intake for the three pathways increased in the following order: $\mathrm{ADI}_{\text {Inal }}<$ $\mathrm{ADI}_{\text {Derm }}<\mathrm{ADI}_{\text {Ing }}$ for adults and children. Comparing the ADI for children and adults shows that the acceptable daily intake for children is lower by ingestion and dermally, which means that this age group is more susceptible to these routes. The acceptable dose intake for adults will already pose a risk to the health of children. The studies conducted in Nigeria and São Paulo reported the same results, finding children more susceptible to a higher level of exposure dose than adults (Lange, 2018; Bwatanglang et al., 2019). 
Table 4. Acceptable daily intake $\left(\mathrm{mg} \mathrm{Kg}^{-1}\right)$ by metal and exposure pathway for adults and children in a Volta Redonda condominium.

\begin{tabular}{cccccc}
\hline & $\mathrm{Zn}$ & $\mathrm{Ni}$ & $\mathrm{Cu}$ & $\mathrm{Cr}$ & $\mathrm{Pb}$ \\
\hline $\mathrm{C}_{\text {Soil }}(95 \% \mathrm{UCL})$ & $1.07 \mathrm{E}+02$ & $1.53 \mathrm{E}+01$ & $2.25 \mathrm{E}+01$ & $5.92 \mathrm{E}+01$ & $2.10 \mathrm{E}+01$ \\
Adults & & & & & \\
ADI Ing & $5.11 \mathrm{E}-05$ & $7.31 \mathrm{E}-06$ & $1.07 \mathrm{E}-05$ & $2.83 \mathrm{E}-05$ & $1.00 \mathrm{E}-05$ \\
ADI $_{\text {Inal }}$ & $7.74 \mathrm{E}-09$ & $1.11 \mathrm{E}-09$ & $1.63 \mathrm{E}-09$ & $4.29 \mathrm{E}-09$ & $1.52 \mathrm{E}-09$ \\
ADI $_{\text {Derm }}$ & $2.04 \mathrm{E}-07$ & $2.91 \mathrm{E}-08$ & $4.29 \mathrm{E}-08$ & $1.13 \mathrm{E}-07$ & $4.00 \mathrm{E}-08$ \\
Children & & & & & \\
ADI Ing $_{\text {ADI }}$ & $4.77 \mathrm{E}-04$ & $6.82 \mathrm{E}-05$ & $1.00 \mathrm{E}-04$ & $2.64 \mathrm{E}-04$ & $9.36 \mathrm{E}-05$ \\
ADI $_{\text {Inal }}$ & $1.37 \mathrm{E}-08$ & $1.96 \mathrm{E}-09$ & $2.89 \mathrm{E}-09$ & $7.60 \mathrm{E}-09$ & $2.69 \mathrm{E}-09$ \\
ADI $_{\text {Derm }}$ & $3.81 \mathrm{E}-06$ & $5.45 \mathrm{E}-07$ & $7.89 \mathrm{E}-08$ & $2.11 \mathrm{E}-06$ & $7.49 \mathrm{E}-07$ \\
\hline
\end{tabular}

$\mathrm{C}_{\text {Soil }}$ : Soil concentration; UCL: Upper confidence limit; $\mathrm{ADI}_{\text {Ing: }}$ Acceptable daily intake by ingestion; $\mathrm{ADI}_{\text {Inal }}$ : Acceptable daily intake by inhalation; $\mathrm{ADI}_{\text {Derm: }}$ : Acceptable daily transdermal intake.

Table 5. Non-carcinogenic hazard quotient (HQ) by metal and exposure pathway for adults and children in a Volta Redonda condominium.

\begin{tabular}{cccccc}
\hline & $\mathrm{Zn}$ & $\mathrm{Ni}$ & $\mathrm{Cu}$ & $\mathrm{Cr}$ & $\mathrm{Pb}$ \\
\hline Adults & & & & & \\
$\mathrm{HQ}_{\text {Ing }}$ & $1.70 \mathrm{E}-04$ & $3.66 \mathrm{E}-04$ & $2.68 \mathrm{E}-04$ & $9.43 \mathrm{E}-03$ & $2.86 \mathrm{E}-03$ \\
$\mathrm{HQ}_{\text {Inal }}$ & $2.58 \mathrm{E}-08$ & $1.85 \mathrm{E}-04$ & $4.08 \mathrm{E}-08$ & $1.50 \mathrm{E}-04$ & $4.34 \mathrm{E}-07$ \\
$\mathrm{HQ}_{\text {Derm }}$ & $6.80 \mathrm{E}-07$ & $3.64 \mathrm{E}-05$ & $1.07 \mathrm{E}-06$ & $1.51 \mathrm{E}-03$ & $5.71 \mathrm{E}-06$ \\
HI & $1.71 \mathrm{E}-04$ & $5.87 \mathrm{E}-04$ & $2.69 \mathrm{E}-04$ & $1.11 \mathrm{E}-02$ & $2.86 \mathrm{E}-03$ \\
Children & & & & & \\
HQ & $1.59 \mathrm{E}-03$ & $3.41 \mathrm{E}-03$ & $2.50 \mathrm{E}-03$ & $8.80 \mathrm{E}-02$ & $2.67 \mathrm{E}-02$ \\
HQ & $4.57 \mathrm{E}-08$ & $3.27 \mathrm{E}-04$ & $7.23 \mathrm{E}-08$ & $2.66 \mathrm{E}-04$ & $7.69 \mathrm{E}-07$ \\
HQ & $1.27 \mathrm{E}-05$ & $6.81 \mathrm{E}-04$ & $1.97 \mathrm{E}-06$ & $2.81 \mathrm{E}-02$ & $1.07 \mathrm{E}-04$ \\
HI & $1.60 \mathrm{E}-03$ & $4.42 \mathrm{E}-03$ & $2.50 \mathrm{E}-03$ & $1.16 \mathrm{E}-01$ & $2.69 \mathrm{E}-02$ \\
\hline
\end{tabular}

$\mathrm{HQ}_{\text {Ing: }}$ Hazard quotient by ingestion; $\mathrm{HQ}_{\text {Inal }}$ : Hazard quotient by inhalation; HQDerm: Hazard quotient by dermal; HI: Health index.

Table 6. Cancer risk index (CRI) by metal and exposure pathway for adults and children in a Volta Redonda condominium.

\begin{tabular}{ccc}
\hline & $\mathrm{Ni}$ & $\mathrm{Cr}$ \\
\hline Adults & & \\
CRI $_{\text {Ing }}$ & - & $1.42 \mathrm{E}-05$ \\
CRI $_{\text {Inal }}$ & $1.09 \mathrm{E}-08$ & $1.76 \mathrm{E}-09$ \\
CRI $_{\text {Derm }}$ & $2.85 \mathrm{E}-07$ & $2.26 \mathrm{E}-08$ \\
TCRI & $2.96 \mathrm{E}-07$ & $1.42 \mathrm{E}-05$ \\
Children & & \\
CRI $_{\text {Ing }}$ & - & $1.32 \mathrm{E}-04$ \\
CRI $_{\text {Inal }}$ & $1.92 \mathrm{E}-08$ & $3.12 \mathrm{E}-09$ \\
CRI $_{\text {Derm }}$ & $5.34 \mathrm{E}-06$ & $4.22 \mathrm{E}-07$ \\
TCRI & $5.36 \mathrm{E}-06$ & $1.32 \mathrm{E}-04$ \\
\hline
\end{tabular}

$\mathrm{CRI}_{\text {Ing: }}$ Cancer risk index by ingestion; $\mathrm{CRI}_{\text {Inal }}$ : Cancer risk index by inhalation;

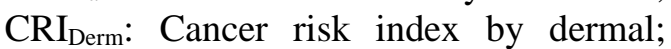
TCRI: Combined effect for each exposure pathway. 
As described in Table 5, the results obtained for the non-carcinogenic hazard quotient (HQ) for adults and children indicated the oral route as a significant contributor to the total risk, followed by dermal absorption and inhalation of soil particles. The exception was Ni in adults, whose inhalation route contributed more than the dermal. The sum of the respective HQ values by route of exposure resulted in a health index $(\mathrm{HI})<1$ for all exposure pathways in adults and children. Therefore, health risks are not expected to occur. However, the HI results obtained for children were about an order of magnitude higher than those obtained for adults, indicating that exposure to metals poses a greater risk to children's health. The decreasing order of HI observed was $\mathrm{Cr}>\mathrm{Pb}>\mathrm{Ni}>\mathrm{Cu}>\mathrm{Zn}$ for both receptors. A study developed in São Paulo reported the same findings, whereby children presented higher values in all exposure routes (Lange, 2018).

Table 6 shows the cancer risk index (CRI) for adults and children. The CRI was only calculated for chromium and nickel since both are classified as Group 1, carcinogenic to humans, by IARC. We did not evaluate lead as it belongs to Group 2A, probably carcinogenic to humans (IARC, 2012). Only the total chromium concentration was determined in the soil samples. However, as $\mathrm{Cr}^{6+}$ is present in steel slag and is more stable than $\mathrm{Cr}^{3+}$ in the environment (ATSDR, 2012), we assume that all chromium is VI following the precautionary principle (Lieber, 2008). The chromium cancer risk was analyzed considering all exposure pathways, whereas only inhalation and dermal contact were considered for $\mathrm{Ni}$, as the cancer slope factor (CSF) for ingestion was not estimated in the literature. The CRI is considered negligible if $<10^{-6}$, acceptable or tolerable if $10^{-6}<\mathrm{CRI}<10^{-4}$, and high if $>10^{-4}$ (Lange, 2018; Bwatanglang et al., 2019). According to Table 6, only the CRI Ing for children is above $10^{-4}$ (1.32E-04) for chromium, which is an unacceptable risk. Although CRI Ing for chromium in adults is (1.42E-05), within the tolerable range, the combined effect for each exposure pathway (TCRI) will undoubtedly exceed $10^{-4}$ after exposure to other carcinogens (volatile organic compounds) present at the site. The TCRI obeyed the following order for both age groups, $\mathrm{Cr}$ $>\mathrm{Ni}$, and showed a likelihood of carcinogenic risk by ingestion in adults (1.42E-05) and potential risk by ingestion in children (1.32E-04), both with chromium. The authors of the study in São Paulo also found a potential risk for $\mathrm{Cr}$ by ingestion in children (1.14E-04) (Lange, 2018). A health risk assessment in Nigeria also attributed the potential cancer risk to $\mathrm{Cr}$ exposure by ingestion in children (Bwatanglang et al., 2019).

Children are more susceptible to health risks compared to adults, as they differ concerning physiology, metabolism, growth, development, and behavior (Perlroth and Branco, 2017). The vulnerability of children compared to adults, as observed in the ingestion pathway, may be related to higher ingestion rates per unit of body weight, in which the unintentional oral contact with contaminated soils is an additional contributing factor for their increased susceptibility (Lange, 2018; Sun and Chen, 2018; Bwatanglang et al., 2019). Children have greater absorption of contaminants through the gastrointestinal tract. The metabolic rate of children is faster, so they digest their meals more quickly than adults. Because they are in the process of growing, their organs have not yet fully developed; even relatively small amounts can cause irreversible damage (Perlroth and Branco, 2017). Our findings regarding TCRI were in line with those reported in the literature (Lange, 2018; Sun and Chen, 2018; Bwatanglang et al., 2019), which found exposure by ingestion to be the major contributor to cancer in children. These authors also found the ingestion of dust or soil with high metal concentrations to increase metal levels in children's blood (Lange, 2018; Sun and Chen, 2018; Bwatanglang et al., 2019).

\section{CONCLUSIONS}

A continuous exposure assessment of this population through biological and environmental monitoring is necessary, since levels of metals $(\mathrm{Zn}, \mathrm{Ni}, \mathrm{Cu}, \mathrm{Cr}, \mathrm{Pb})$ in the soil of the Condominium are generally high. 
Children cannot be exposed to the same doses as adults since they are more susceptible and risk further damage to health. Thus, the acceptable daily intake must be lower than that of adults.

The results showed an immediate carcinogenic risk by chromium ingestion for children. Nevertheless, the combined effect for each exposure pathway (TCRI) for adults is close to becoming unacceptable after exposure to $\mathrm{Cr}$ by ingestion.

After exposure to the soil by any route, metal contamination is more likely to occur among children than adults at similar exposure levels. Thus, the condominium built over an area contaminated by steel industry waste raises concern, requiring the continuous monitoring of its population.

\section{REFERENCES}

ABNT. NBR 15492: Sondagem de reconhecimento para fins de qualidade ambiental Procedimento. Rio de Janeiro, 2007.

APHA; AWWA; WEF. Standard Methods for the examination of water and wastewater. 22nd ed. Washington, 2012. 1496 p.

ATSDR. Toxicological profile for chromium. Atlanta, 2012. Available in: https://www.atsdr.cdc.gov/toxprofiles/tp7.pdf. Access in: 05 June 2021.

BRASIL. Procuradoria da República. Ação civil pública, com pedido de antecipação dos efeitos da tutela in limine. Volta Redonda: MPF, 2012. Available in: http://www.prrj.mpf.mp.br/arquivos_pdf/ACP\%20CSN\%20VOLTA\%20GRANDE\%20 IV.pdf. Access in: 13 Feb. 2019.

BRASIL. Procuradoria da República. Ação civil pública, com pedido de liminar. Volta Redonda: MPF, 2015. 74f.

BWATANGLANG, I. B.; ALEXANDER, P.; TIMOTHY, N. A. Vehicle-Derived Heavy Metals and Human Health Risk Assessment of Exposure to Communities along MubiYola Highway in Adamawa State (Nigeria). Journal of Scientific Research and Reports, v. 23, n. 1, p. 1-13, 2019. https://doi.org/10.9734/jsrr/2019/v23i130110

CETEM. Desafios de Sustentabilidade Ambiental para a Siderurgia Brasileira. 2013a. Available in: http://verbetes.CETEM.gov.br/verbetes/ExibeVerbete.aspx?verid=147. Access in: 15 Feb. 2020.

CETEM. Volta Redonda (RJ) convive com efeitos cumulativos de 71 anos de atividade siderúrgica. 2013b. Available in: http://verbetes.CETEM.gov.br/verbetes/ExibeVerbete.aspx?verid=135. Access in: 15 Feb. 2020.

CETESB. Valores orientadores para solo e água subterrânea no Estado de São Paulo 2016. São Paulo, 2016. Available in: https://CETESB.sp.gov.br/aguas-subterraneas/wpcontent/uploads/sites/13/2013/11/tabela_vos_2016_site.pdf. Access in: 21 Dec. 2020.

FAO. Working document for information and use in discussions related to contaminants and toxins in the Gsctff. Fifth Session. The Hague, 2011. 90 p. Available in: http://www.FAO.org/tempref/codex/Meetings/CCCF/CCCF5/cf05_INF.pdf. Access in: 19 Mar. 2020. 
GABARRÓN, M.; FAZ, A.; ACOSTA, J. A. Soil or dust for health risk assessment studies in urban environment. Archives of Environmental Contamination and Toxicology, v. 73, n. 3, p. 442-455, 2017. https://doi.org/10.1007/s00244-017-0413-x

GENCHI, G.; CAROCCI, A.; LAURIA, G.; SINICROPI, M. S.; CATALANO, A. Review Nickel: Human Health and Environmental Toxicology. International Journal of Environmental Research and Public Health, v. 17, n. 3, p. 679, 2020. https://doi:10.3390/ijerph17030679

HSU, C. Y.; CHIANG, H. C.; CHEN, M. J.; CHUANG, C. Y.; TSEN, C. M.; FANG, G. C. et al. Ambient PM 2.5 in the residential area near industrial complexes: Spatiotemporal variation, source apportionment, and health impact. Science of the Total Environment, v. 590-591, p. 204-214, 2017. https://doi.org/10.1016/j.scitotenv.2017.02.212

IARC. A review of human carcinogens. Part C: Arsenic, metals, fibres, and dusts. IARC monographs on the evaluation of carcinogenic risks to humans. Lyon, 2012. v. 100C. 527 p.

INEA. Plano estadual de recursos hídricos do estado do Rio de Janeiro. Rio de Janeiro, 2014.

Available

in: http://www.inea.rj.gov.br/cs/groups/public/documents/document/zwew/mdcx/ edisp/ine a0071538.pdf. Access in: 12 Jan. 2020.

LANGE, C. N. Avaliação da contaminação de solos e água subterrânea por elementos potencialmente tóxicos em um patio de recolhimento de veículos. Estudo de caso: Ribeirão Pires, SP. 2018. 145f. Tese (Doutorado em Ciências) - Instituto de Pesquisas Energéticas e Nucleares, São Paulo, 2018.

LAWTON, K.; CHERRIER, V.; GREBOT, B.; ZGLOBISZ, N.; ESPARRAGO, J.; GANZLEBEN, C. et al. Study on: Contribution of industry to pollutant emissions to air and water. Luxembourg: Publications Office of the European Union, 2014. 293 p.

LIEBER, R. R. O Princípio da precaução e a saúde no trabalho. Saúde e Sociedade, v. 17, n. 4, p. 124-134, 2008. https://doi.org/10.1590/S0104-12902008000400013

LU, X.; WU, X.; WANG, Y.; CHEN, H.; GAO, P.; FU, Y. Risk assessment of toxic metals in street dust from a medium-sized industrial city of China. Ecotoxicology and $\begin{array}{llllll}\text { Environmental Safety, } & \text { v. } & 106, & \end{array}$ https://doi.org/10.1016/j.ecoenv.2014.04.022

MASINDI, V.; MUEDI, K. L. Environmental Contamination by heavy metals. IntechOpen, 2018. chapter 7. https://doi:10.5772/intechopen.76082

MOTUZOVA, G. V.; MINKINA, T. M.; KARPOVA, E. A.; BARSOVA, N. U.; MANDZHIEVA, S. S. Soil contamination with heavy metals as a potential and real risk to the environment. Journal of Geochemical Exploration, v. 144, p. 241-246, 2014. https://doi.org/10.1016/j.gexplo.2014.01.026

OGUNDELE, D. T.; ADIO, A. A.; OLUDELE, O. E. Heavy Metal Concentrations in Plants and Soil along Heavy Traffic Roads in North Central Nigeria. Journal of Environmental \& Analytical Toxicology, v. 5, p. 334, 2015. https://doi.org/10.4172/2161-0525.1000334

PERLROTH, N. H.; BRANCO, C. W. C. Current knowledge of environmental exposure in children during the sensitive developmental periods. Jornal de Pediatria, v. 93, n. 1, p. 17 - 27, 2017. https://doi.org/10.1016/j.jped.2016.07.002 
PLUM, L. M.; RINK, L.; HAASE, H. The Essential Toxin: Impact of Zinc on Human Health. International Journal of Environmental Research and Public Health, v. 7, n. 4, p. 1342-1365, 2010. https://doi.org/10.3390/ijerph7041342

ROSENFELD, P. E.; FENG, L. G. H. Iron, Steel, and Coke. Risks of Hazardous Wastes, p. 83-94, 2011. https://doi.org/10.1016/B978-1-4377-7842-7.00007-6

SALL, M. L.; DIAW, A. K. D.; GNINGUE-SALL, D.; AARON, S. E.; AARON, J. Toxic heavy metals: impact on the environment and human health, and treatment with conducting organic polymers, a review. Environmental Science and Pollution Research, v. 27, p. 29927-29942, 2020. https://doi.org/10.1007/s11356-020-09354-3

SILVA, A. P.; ASMUS, C. I. F.; PAVIN, J. L. P.; LACERDA, J. C. V.; SALES, L. B. F.; RESENDE, M. T. et al. Estudo de avaliação de risco à saúde humana em localidades atingidas pelo rompimento da barragem do Fundão - MG. 2019. São Paulo: AMBIOS, 2019. 369 p.

SINGHAL, V. K.; DESWAL, B. S; SINGH, B. Study of skin and mucous membrane disorders among workers engaged in the sodium dichromate manufacturing industry and chrome plating industry. Indian Journal of Occupational and Environmental Medicine, v. 19, n. 3, p. 129-133, 2015. https://doi: 10.4103/0019-5278.173994

SOARES, M. R.; CASAGRANDE, J. C.; MOUTA, E. R. Nickel adsorption by variable charge soils: effect of $\mathrm{pH}$ and Ionic strength. Brazilian Archives of Biology and Technology, v. 54, n. 1, p. 207-220, 2011. https://doi.org/10.1590/S1516-89132011000100025

SÓCIO, S. A.; FERREIRA, A. R.; FAGUNDES, E. D. T.; ROQUETE, M. L. V.; PIMENTA, J. R.; CAMPOS, L. F. et al. Doença de Wilson em crianças e adolescentes: diagnóstico e tratamento. Revista Paulista de Pediatria, v. 28, n. 2, 2010. https://doi.org/10.1590/S0103-05822010000200002

SUN, Z.; CHEN, J. Risk assessment of potentially toxic elements (PTEs) pollution at a rural industrial wasteland in an abandoned metallurgy factory in North China. International Journal of Environmental Research and Public Health, v. 15, n. 1, p. 85, 2018. https://doi.org/10.3390/ijerph15010085

TÓTH, G.; HERMANN, T.; DA SILVA, M. R.; MONTANARELLA, L. Heavy metals in agricultural soils of the European Union with implications for food safety. Environment International, v. 88, p. 299-309, 2016. https://doi.org/10.1016/j.envint.2015.12.017

TSAFE, A. I.; HASSAN, L. G.; SAHABI, D. M.; ALHASSAN, Y.; BALA, B. M. Evaluation of heavy metals uptake and risk assessment of vegetables grown in Yargalma of Northern Nigeria. Journal of Basic and Applied Scientific Research, v. 2, n. 7, p. 6708-6714, 2012.

USEPA. Calculating upper confidence limits for exposure point concentrations at hazardous waste sites. Washington, D.C., 2002.

USEPA. Guidelines of exposure assessment. Washington, D.C., 1992.

USEPA. Risk assessment guidance for superfund volume I: Human health evaluation manual (Part A). Office of emergency and remedial response. Washington, D.C., 1989.

USEPA. Risk assessment guidance for superfund volume I: Human health evaluation manual (Part E, Supplemental guidance for dermal risk assessment). Washington, D.C., 2004. 
USEPA. Soil screening guidance: Technical background document. Washington, D.C., 1996.

USEPA. Superfund public health evaluation manual. Washington, D.C., 1986.

ZHANG, J.; MATSUURA, H.; TSUKIHASHI, F. Processes for Recycling. Treatise on Process Metallurgy, v. 3, p. 1507-1561, 2014. https://doi.org/10.1016/B978-0-08096988-6.00036-5 